\title{
TU/e EmonOWEN

\section{Low temperature temporal and spatial atomic layer deposition of TiO2 films}

\section{Citation for published version (APA):}

Aghaee, M., Maydannik, P. S., Johansson, P., Kuusipalo, J., Creatore, M., Homola, T., \& Cameron, D. C. (2015). Low temperature temporal and spatial atomic layer deposition of TiO2 films. Journal of Vacuum Science and Technology A: Vacuum, Surfaces, and Films, 33, 041512-1/10. https://doi.org/10.1116/1.4922588

DOI:

$10.1116 / 1.4922588$

Document status and date:

Published: 01/01/2015

\section{Document Version:}

Publisher's PDF, also known as Version of Record (includes final page, issue and volume numbers)

\section{Please check the document version of this publication:}

- A submitted manuscript is the version of the article upon submission and before peer-review. There can be important differences between the submitted version and the official published version of record. People interested in the research are advised to contact the author for the final version of the publication, or visit the $\mathrm{DOI}$ to the publisher's website.

- The final author version and the galley proof are versions of the publication after peer review.

- The final published version features the final layout of the paper including the volume, issue and page numbers.

Link to publication

\section{General rights}

Copyright and moral rights for the publications made accessible in the public portal are retained by the authors and/or other copyright owners and it is a condition of accessing publications that users recognise and abide by the legal requirements associated with these rights.

- Users may download and print one copy of any publication from the public portal for the purpose of private study or research.

- You may not further distribute the material or use it for any profit-making activity or commercial gain

- You may freely distribute the URL identifying the publication in the public portal.

If the publication is distributed under the terms of Article 25fa of the Dutch Copyright Act, indicated by the "Taverne" license above, please follow below link for the End User Agreement:

www.tue.nl/taverne

Take down policy

If you believe that this document breaches copyright please contact us at:

openaccess@tue.nl

providing details and we will investigate your claim. 


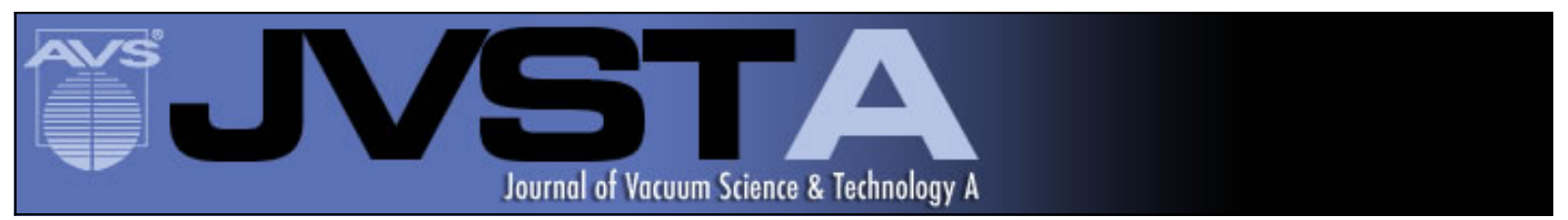

\section{Low temperature temporal and spatial atomic layer deposition of $\mathrm{TiO} 2$ films}

Morteza Aghaee, Philipp S. Maydannik, Petri Johansson, Jurkka Kuusipalo, Mariadriana Creatore, Tomáš Homola, and David C. Cameron

Citation: Journal of Vacuum Science \& Technology A 33, 041512 (2015); doi: 10.1116/1.4922588

View online: http://dx.doi.org/10.1116/1.4922588

View Table of Contents: http://scitation.aip.org/content/avs/journal/jvsta/33/4?ver=pdfcov

Published by the AVS: Science \& Technology of Materials, Interfaces, and Processing

\section{Articles you may be interested in}

Spatial atomic layer deposition: Performance of low temperature $\mathrm{H} 2 \mathrm{O}$ and $\mathrm{O} 3$ oxidant chemistry for flexible electronics encapsulation

J. Vac. Sci. Technol. A 33, 031603 (2015); 10.1116/1.4914079

Enhanced photocatalytic performance in atomic layer deposition grown $\mathrm{TiO} 2$ thin films via hydrogen plasma treatment

J. Vac. Sci. Technol. A 33, 01A152 (2015); 10.1116/1.4904503

Characterization of low temperature deposited atomic layer deposition TiO2 for MEMS applications

J. Vac. Sci. Technol. A 31, 01A148 (2013); 10.1116/1.4772664

Low temperature deposition of $\mathrm{Ga} 2 \mathrm{O} 3$ thin films using trimethylgallium and oxygen plasma

J. Vac. Sci. Technol. A 31, 01A110 (2013); 10.1116/1.4758782

Electrical characteristics of Ga $2 \mathrm{O} 3$ - TiO 2 nanomixed films grown by plasma-enhanced atomic-layer deposition for gate dielectric applications

Appl. Phys. Lett. 87, 082909 (2005); 10.1063/1.2034100

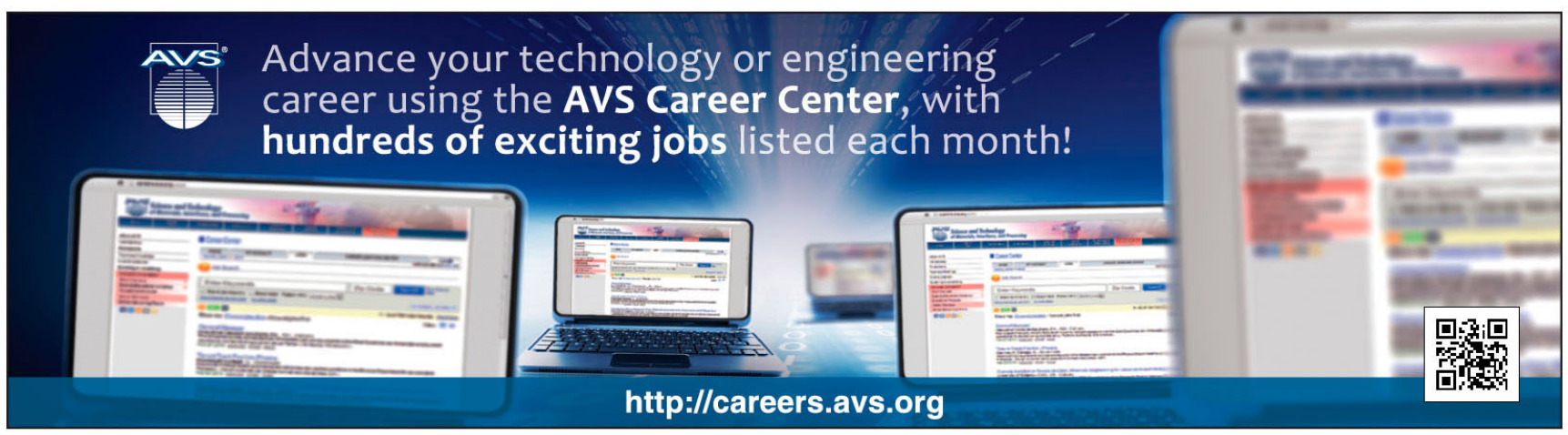




\title{
Low temperature temporal and spatial atomic layer deposition of $\mathrm{TiO}_{2}$ films
}

\author{
Morteza Aghaee ${ }^{\text {a) }}$ and Philipp S. Maydannik \\ ASTRaL Group, Laboratory of Green Chemistry, Lappeenranta University of Technology, Sammonkatu 12, \\ 50130 Mikkeli, Finland \\ Petri Johansson and Jurkka Kuusipalo \\ Paper Converting and Packaging Technology, Tampere University of Technology, P.O. Box 541, \\ FI-33101 Tampere, Finland \\ Mariadriana Creatore \\ Department of Applied Physics, Eindhoven University of Technology, P.O. Box 513, 5600 MB Eindhoven, \\ The Netherlands \\ Tomáš Homola and David C. Cameron \\ $R \& D$ Center for Low-Cost Plasma and Nanotechnology Surface Modification, Masaryk University, \\ Kotlářská 2, 61137 Brno, Czech Republic
}

(Received 23 March 2015; accepted 1 June 2015; published 17 June 2015)

\begin{abstract}
Titanium dioxide films were grown by atomic layer deposition (ALD) using titanium tetraisopropoxide as a titanium precursor and water, ozone, or oxygen plasma as coreactants. Low temperatures $\left(80-120^{\circ} \mathrm{C}\right)$ were used to grow moisture barrier $\mathrm{TiO}_{2}$ films on polyethylene naphthalate. The maximum growth per cycle for water, ozone, and oxygen plasma processes were $0.33,0.12$, and $0.56 \AA$ A cycle, respectively. X-ray photoelectron spectrometry was used to evaluate the chemical composition of the layers and the origin of the carbon contamination was studied by deconvoluting carbon C1s peaks. In plasma-assisted ALD, the film properties were dependent on the energy dose supplied by the plasma. $\mathrm{TiO}_{2}$ films were also successfully deposited by using a spatial ALD (SALD) system based on the results from the temporal ALD. Similar properties were measured compared to the temporal ALD deposited $\mathrm{TiO}_{2}$, but the deposition time could be reduced using SALD. The $\mathrm{TiO}_{2}$ films deposited by plasma-assisted ALD showed better moisture barrier properties than the layers deposited by thermal processes. Water vapor transmission rate values lower than $5 \times 10^{-4} \mathrm{~g} \mathrm{day}^{-1} \mathrm{~m}^{-2}\left(38^{\circ} \mathrm{C}\right.$ and $\left.90 \% \mathrm{RH}\right)$ was measured for $20 \mathrm{~nm}$ of $\mathrm{TiO}_{2}$ film deposited by plasma-assisted ALD. (C) 2015 American Vacuum Society.
\end{abstract}

[http://dx.doi.org/10.1116/1.4922588]

\section{INTRODUCTION}

Atomic layer deposition (ALD) is a thin film deposition technique, which offers some superior properties over other existing thin film deposition methods, for example, it can produce conformal films with angstrom scale thickness control. ${ }^{1,2}$ In addition, the self-limiting nature of surface reactions in ALD leads to the production of continuous pinholefree films, which can be applied successfully on high aspect ratio surfaces. Different metals, metal oxides, and nitrides can be deposited using this method at relatively low temperatures. ${ }^{3-5}$ The unique properties of the ALD method also meet the demanding requirements of industries such as semiconductors and microelectronics: indeed, they have been widely used for nanoscale device fabrication. ${ }^{6}$ As distinct from conventional temporal ALD, which has an alternating sequence of precursor exposure, spatial ALD (SALD) is a high throughput ALD method, which is compatible with flexible continuous substrates and large scale thin film production. $^{7}$ The concept of spatial ALD leads to the same sequence of precursor and purge gas exposure as conventional temporal ALD. In this method, the substrate is exposed to a coating head, which consists of several spatially

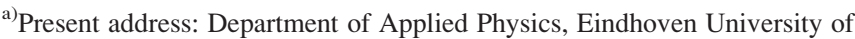
Technology, P.O. Box 513, 5600 MB Eindhoven, The Netherlands; electronic mail: m.aghaee@tue.nl
}

separated precursor and purge zones. One half reaction occurs when the substrate passes through a precursor gas zone, which is separated from the other precursor zone by a purge zone. The schematic and real views of different configurations of spatial and roll-to-roll ALD systems can be found in Refs. 7-11.

ALD layers have been shown to have the capability of being used as moisture barriers for organic light emitting diodes (OLEDs). ${ }^{12}$ One of the major obstacles to the realization of flexible OLEDs as well as thin film solar cells is a reliable thin-film encapsulation. The level of water vapor transmission rate (WVTR) that is required for the abovementioned applications is below $10^{-6} \mathrm{~g}_{\text {day }}{ }^{-1} \mathrm{~m}^{-2}$ to ensure a lifetime of above $10000 \mathrm{~h}^{13}$ The value of WVTR for polymers is many orders of magnitude higher than this. ${ }^{14}$ However, a thin film barrier coating deposited by ALD could provide such properties to a polymer layer and make it suitable for flexible electronic applications. A low temperature process is required for coating on polymers and other temperature sensitive substrates. ${ }^{15-20}$ At relatively high temperatures, although still lower than the polymer melting point, thermal degradation can occur changing the polymer physical and mechanical properties. ${ }^{21}$ In addition, lowering the process temperature can also decrease the mechanical stress induced by differences in the coefficient of thermal expansion between the film and polymer 
substrate during cooling, responsible for the appearance of cracks in the film. ${ }^{22-24}$

Several single layers and multilayer stacks of $\mathrm{TiO}_{2}, \mathrm{Al}_{2} \mathrm{O}_{3}$, and $\mathrm{ZnO}$ prepared by thermal and plasma-assisted ALD on polymer substrates have been used for encapsulation and moisture barrier purpose. ${ }^{25-27}$ Among these oxides, titanium dioxide is a promising material with good stability against degradation. Several ALD studies on titanium dioxide have been carried out using different titanium precursors. $\mathrm{TiCl}_{4}{ }^{28}$ $\mathrm{TiI}_{4}{ }^{29}$ tetrakis-dimethyl-amido titanium (TDMAT), ${ }^{30}$ titanium tetraisopropoxide (TTIP), ${ }^{31}$ titanium ethoxide, ${ }^{32}$ and titanium methoxide ${ }^{33}$ were used in order to deposit titanium dioxide ALD films. Among these precursors, TTIP is costefficient and has the highest vapor pressure among titanium metalorganics, which makes it an interesting precursor for developing for large scale and roll-to-roll ALD processes.

In this paper, relatively low temperatures have been used for atomic layer deposition of titanium dioxide moisture barrier films on polymer surfaces using TTIP. Water, ozone, and oxygen plasma have been used as the oxidising precursor in $\mathrm{TiO}_{2}$ temporal ALD processes. WVTR values lower than $5 \times 10^{-4} \mathrm{~g}$ day $^{-1} \mathrm{~m}^{-2}$ have been measured in tropical condition for a single $20 \mathrm{~nm} \mathrm{TiO}_{2}$ layer deposited on polyethylene naphthalate (PEN) by plasma-assisted atomic layer deposition in a temporal ALD system. The preliminary results of the temporal ALD were used to develop a spatial ALD process, using TTIP and water as precursors, and the film properties were studied.

\section{EXPERIMENT}

\section{A. Temporal ALD}

The samples were prepared using a TFS-200 ALD system (Beneq Oy, Finland) using either a thermal or a plasma process. TTIP (97\% Sigma Aldrich) was used as a titanium precursor and water, $\mathrm{O}_{3}$ and $\mathrm{O}_{2}$ plasma were used as the oxygen source. The titanium precursor bubbler was heated to $65^{\circ} \mathrm{C}$ to obtain a high enough vapor pressure and nitrogen (99.999\%) was used as the carrier gas. The vapor delivery line was heated to $75^{\circ} \mathrm{C}$ in order to prevent vapor condensation. Water was held at $20^{\circ} \mathrm{C}$ and used without carrier gas and the water vapor delivery line was held at room temperature $\left(>20^{\circ} \mathrm{C}\right)$. Ozone was generated using a BMT $803 \mathrm{~N}$ ozone generator, which is able to produce $8 \mathrm{~g} / \mathrm{h}$ ozone with purity of $99.999 \%$ and concentration of $250 \mathrm{~g} / \mathrm{Nm}^{3}$. Each cycle consisted of two precursor pulses, and two purge steps between the precursor pulses and nitrogen $(99.999 \%)$ obtained from liquid nitrogen boil-off was used as the purge gas between precursor pulses. Depositions were carried out between 80 and $120^{\circ} \mathrm{C}$.

The remote plasma system used in the temporal ALD is illustrated in Fig. 1. It is similar to the plasma systems which were used by Kääriäinen and Cameron ${ }^{34}$ and Kariniemi et $a l .{ }^{35}$ Plasma was generated by capacitive coupling with a $13.56 \mathrm{MHz}$ rf plasma source. The distance between the plasma electrode and the substrate surface was $25 \mathrm{~mm}$ and remained constant during all ALD cycles. A grid at ground potential was situated between the plasma electrode and the substrate to avoid ion bombardment of the substrate and the

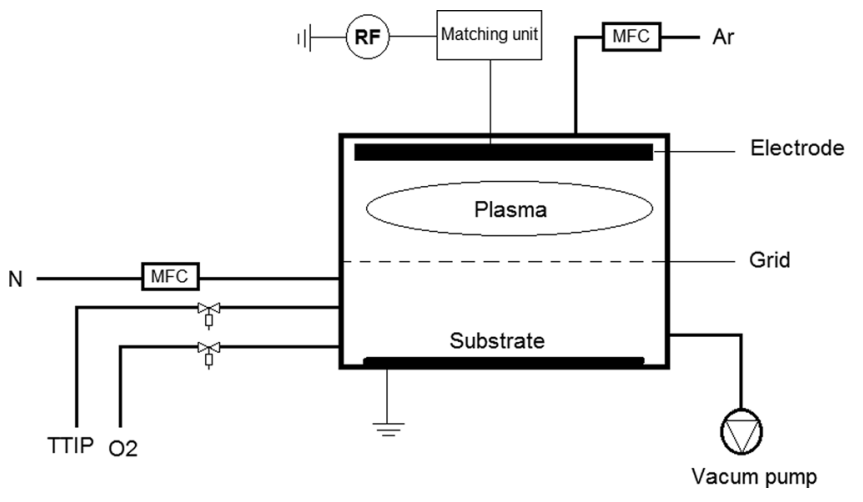

FIG. 1. Schematic view of plasma ALD reactor.

distance between the grid and substrate was $12 \mathrm{~mm}$. Additional argon (99.999\%) was used to facilitate the generation of the plasma. $\mathrm{O}_{2}$ gas $(99.999 \%)$ was introduced to the chamber to produce oxygen radicals. All plasma depositions were done at $80^{\circ} \mathrm{C}$.

Polished (100) silicon wafers were used as substrates for film thickness measurements and X-ray photoelectron spectroscopy analysis (XPS). Teonex ${ }^{\circledR}$ PEN (Polyethylene naphthalate) from DuPont Teijin with thickness of $125 \mu \mathrm{m}$, which is the most popular polymer that has been used for flexible displays, was used as a polymer substrate for WVTR measurements. A clean enclosure with the class of ISO 5 (ISO 14644-1) was used to protect the polymer surface against dust and contaminants.

The film thickness was measured from the film deposited on silicon by using a spectroscopic ellipsometer M-2000UI from J.A. Woollam Co., Inc., between 400 and $1600 \mathrm{~nm}$ using a Cauchy model of the titanium oxide optical characteristics. The growth rate was calculated based on these thickness measurements. The refractive index of the films was measured at the wavelength of $600 \mathrm{~nm}$. XPS analysis was done using a Thermo Scientific ${ }^{\mathrm{TM}} \mathrm{K}$-Alpha ${ }^{\mathrm{TM}}$ system with $\mathrm{Al} \mathrm{k} \alpha(1486.68 \mathrm{eV})$ excitation. The spot size of the $\mathrm{X}$ ray was $400 \mu \mathrm{m}^{2}$ and remained constant in all measurements. The photoelectron takeoff angle was set at $90^{\circ}$, which means that the detector was perpendicular to the sample. $\mathrm{Ar}^{+}$ions were accelerated to $2 \mathrm{keV}$ with $2 \times 4 \mathrm{~mm}^{2}$ raster size to etch the sample surface for $20 \mathrm{~s}$ in order to remove surface contaminants. The water vapor transmission rates of the titanium dioxide films on polymer as well as uncoated polymer were measured using an AQUATRAN ${ }^{\circledR}$ Model1 (MOCON Inc.) system in tropical conditions $\left(38^{\circ} \mathrm{C}\right.$ and $\left.90 \% \mathrm{RH}\right)$. Two parallel measurements were done for each sample and the mean value of them is reported.

\section{B. Spatial ALD}

A TFS-200R spatial ALD system (Beneq Oy, Finland) was used to prepare titanium dioxide films using TTIP and water to study the growth rate of titanium dioxide layers at different deposition temperatures. A schematic view of the spatial ALD reactor is shown in Fig. 2. The reactor consists of a cylindrical chamber with eight precursor nozzles arranged radially, each separated by a nitrogen purge nozzle, which means that four ALD cycles take place in each 


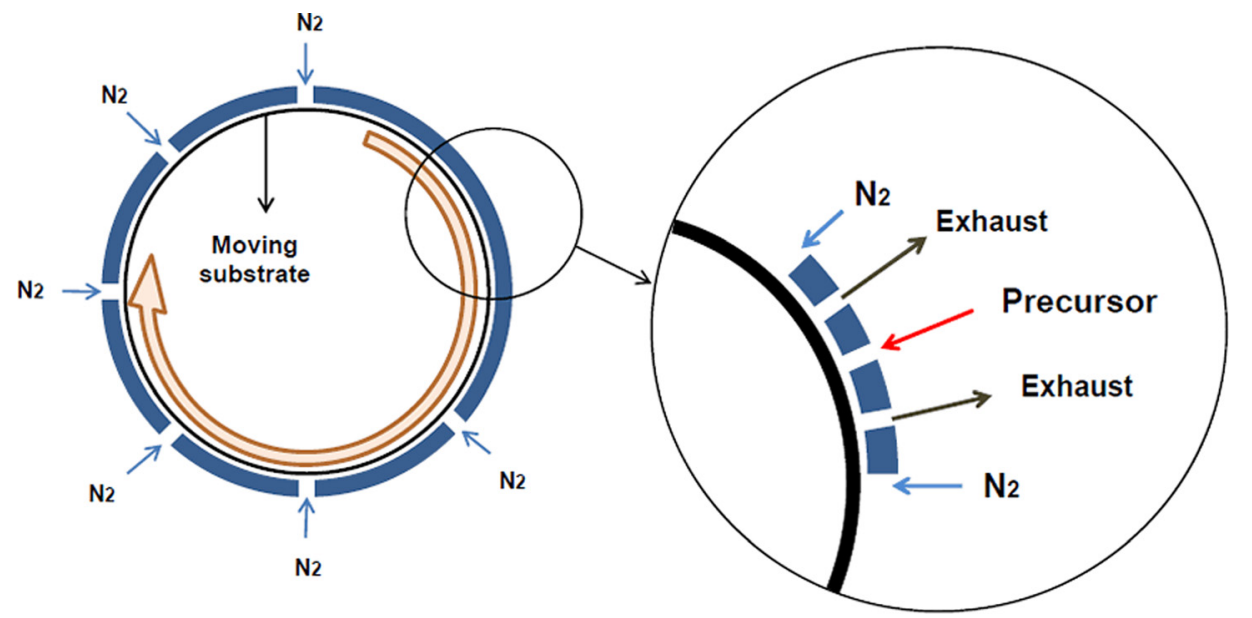

FIG. 2. (Color online) Schematic view of TFS-200R SALD reactor (top view).

rotation of the substrate. The axial length of each nozzle is $120 \mathrm{~mm}$, which is the same as substrate width and the gap between the nozzles and substrate was $500 \mu \mathrm{m}$. The time that one point of the substrate needs to pass one precursor zone is defined as the "residence time." The width of each precursor zone was assumed to be the width of the nozzle, which was $12 \mathrm{~mm}$. This ignores the width of the nitrogen curtain between nozzles. The temperatures of the TTIP and water containers were the same as in the temporal ALD process. Nitrogen with a flow rate of $100 \mathrm{sccm}$ was used as a carrier gas for both TTIP and water. Nitrogen flow of $4600 \mathrm{sccm}$ was also used as a purge gas. Fifty micrometer thick flexible silicon was used in order to measure the film thickness and metallized polymer was used to check the uniformity of the film along the nozzle's length. The carbon content of the films was also measured by XPS.

\section{RESULTS AND DISCUSSION}

\section{A. Film growth by temporal ALD}

\section{Water process}

$\mathrm{TiO}_{2}$ thin films were deposited on silicon using different water and TTIP pulse lengths with $1 \mathrm{~s}$ of purge length after TTIP exposure and 25-50 s of purge length after $\mathrm{H}_{2} \mathrm{O}$ exposure. Purge length up to $25 \mathrm{~s}$ was used for up to $2 \mathrm{~s}$ of $\mathrm{H}_{2} \mathrm{O}$ pulse length and $50 \mathrm{~s}$ for the pulse times more than $2 \mathrm{~s}$. With these purge lengths there was no evidence of non-ALD film growth. Above $500 \mathrm{~ms}$, changes in the TTIP pulse length showed no changes in growth rate and refractive index of the films. However, changing the water pulse length caused significant variations in both the growth rate and the refractive index. The effects of changes in water pulse length were studied by changing the water pulse time between $500 \mathrm{~ms}$ and $3 \mathrm{~s}$. Figure 3 shows the deposition rates and refractive indices of the films, which were deposited using TTIP and water with $\mathrm{ABAB} \ldots$ cycles at 80,100 , and $120^{\circ} \mathrm{C}$. The growth of titanium dioxide on the silicon surface saturated with approximately $2 \mathrm{~s}$ of water pulse, which gave the maximum growth rate of $0.33 \AA$ /cycle at $120^{\circ} \mathrm{C}$. Varying temperature in the range of $80-120^{\circ} \mathrm{C}$ had no significant effect on the growth rate; however, saturation occurred at lower water pulse times for higher temperatures. Xie et al. ${ }^{36}$ measured a growth rate of $0.03-0.15 \AA /$ cycle between 50 and $150{ }^{\circ} \mathrm{C}$. They also reported an increase in the growth rate in the temperature range of $50-150{ }^{\circ} \mathrm{C}$, which does not agree with the results of this study. Both Rahtu and Ritala ${ }^{37}$ and Ritala and Leskelii $^{38}$ reported a growth rate of $0.15 \AA$ /cycle at substrate
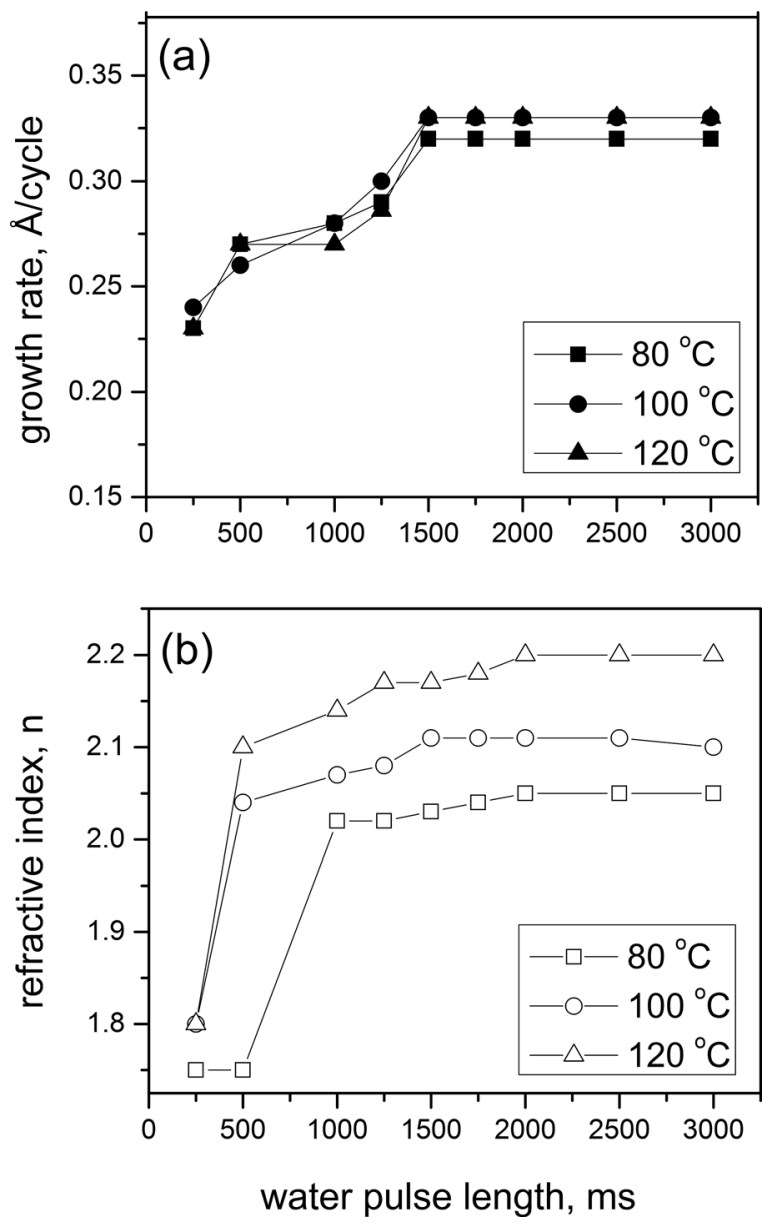

FIg. 3. (a) Growth rate and (b) refractive index of $\mathrm{TiO}_{2}$ films as a function of water pulse length. 
temperature of $150{ }^{\circ} \mathrm{C}$. On the other hand, Döring et al. ${ }^{39}$ reported of $1.5 \AA$ /cycle at the same substrate temperature. Sinha et al..$^{40}$ also measured the growth rate at $160^{\circ} \mathrm{C}$, which was $0.68 \AA$ /cycle. The recent work by Meng et $a l^{41}$ is in better agreement with current work. They measured a growth rate of $0.34 \AA$ /cycle at $150^{\circ} \mathrm{C}$ on an anodic aluminum oxide surface. A wide range of precursor temperature between 25 and $82{ }^{\circ} \mathrm{C}$ was used in the studies referred to. The differences between the deposition rates measured in this and earlier works may be partly due to the different pressure conditions and possibly different dosing conditions. In the present work, the TTIP vapor pressure was higher than in Ref. 42the precursor source temperature, and the process pressure were $65^{\circ} \mathrm{C}$ and about $750 \mathrm{mTorr}$ in this case compared with $45^{\circ} \mathrm{C}$ and 7.5-100 mTorr in the case of Ref. 42 .

The refractive index increased with increasing water pulse length and reached a saturation at $1.5-2 \mathrm{~s}$ for all the three deposition temperatures. An increase in substrate temperature significantly affected the refractive index of the films. For $2 \mathrm{~s}$ of water pulse, the refractive index changed from 2.05 for $80^{\circ} \mathrm{C}$ to 2.2 for $120^{\circ} \mathrm{C}$, showing that the titanium dioxide films are denser at higher temperature [Fig. 3(b)]. X-ray diffraction patterns also showed no evidence of crystallinity, indicating that the films were amorphous as to be expected from the low deposition temperatures. The transition from amorphous to anatase $\mathrm{TiO}_{2}$ has been reported $180^{\circ} \mathrm{C}$ in the thermal ALD. ${ }^{31}$

The mechanisms of the reaction between TTIP and water were studied by Rahtu and Ritala ${ }^{37}$ and Aarik et al. ${ }^{31}$ using deuterated water to identify them. It was found that between 150 and $250^{\circ} \mathrm{C}$ half of the isopropoxide ligands are released during the TTIP pulse in reaction with hydroxyl groups and the other half are released during the water pulse. The two half equations are

$$
\begin{aligned}
2 & -\mathrm{OD}(\mathrm{s})+\mathrm{Ti}\left(\mathrm{OCH}\left(\mathrm{CH}_{3}\right)_{2}\right)_{4}(\mathrm{~g}) \\
& \rightarrow(-\mathrm{O}-) 2 \mathrm{Ti}\left(\mathrm{OCH}\left(\mathrm{CH}_{3}\right)_{2}\right)_{2}(\mathrm{~s})+2\left(\mathrm{CH}_{3}\right)_{2} \mathrm{CHOD}(\mathrm{g}),
\end{aligned}
$$

$$
\begin{aligned}
& (-\mathrm{O}-) 2 \mathrm{Ti}\left(\mathrm{OCH}\left(\mathrm{CH}_{3}\right)_{2}\right)_{2}(\mathrm{~s})+2 \mathrm{D}_{2} \mathrm{O}(\mathrm{g}) \\
& \quad \rightarrow(-\mathrm{O}-) 2 \mathrm{Ti}(-\mathrm{OD})_{2}(\mathrm{~s})+2\left(\mathrm{CH}_{3}\right)_{2} \mathrm{CHOD}(\mathrm{g}),
\end{aligned}
$$

where D represents deuterium. For temperatures higher than $250^{\circ} \mathrm{C}$, one isopropoxide group reacts with one surface hydroxyl group and the other three isopropoxide groups react with the water pulse. Generally, it has been shown for several ALD processes using water that the hydroxyl coverage is better on the surface in low temperatures and decreases with increasing temperature. ${ }^{43,44}$ As the temperature increases, some hydroxyl groups probably combine to form water molecules, which are removed from the surface. ${ }^{45}$

$$
2-\mathrm{OH} \rightarrow-\mathrm{O}+\mathrm{H}_{2} \mathrm{O}(\mathrm{g}) .
$$

This dehydroxylation leads to reduction in $-\mathrm{OH}$ groups on the surface at elevated temperature. In thermal ALD, the complete reaction of surface groups and incoming precursors happens in the presence of adequate thermal energy.
Absence of adequate thermal energy for the reaction of TTIP and surface $-\mathrm{OH}$ at low surface temperatures $\left(80-120^{\circ} \mathrm{C}\right)$ could be a reason for the low growth rate of titanium dioxide. There is also the possibility of forming water multilayers for the long water pulse length at temperatures lower than $100^{\circ} \mathrm{C}^{46}$ Quartz crystal microbalance measurements made by Aarik et al. ${ }^{31}$ for TTIP and water at $100^{\circ} \mathrm{C}$ revealed a mass decrease immediately after the water pulse that is related to water desorption from the surface. Desorption of molecular water from the surface will take a longer time when the temperature is as low as $80^{\circ} \mathrm{C}$. Insufficient purge times may lead to incomplete water desorption from surface and consequently anomalous growth of the oxide by a CVD process. In this work, the effects of purge time were also tested during deposition of titanium dioxide from TTIP and water. It was found that the purge times as long as $50 \mathrm{~s}$ are needed after $4 \mathrm{~s}$ of water exposure, but for $2 \mathrm{~s}$ of water pulse, $25 \mathrm{~s}$ of purge time is enough. Thus, with increasing water pulse time, much higher purge times are needed to remove excess water molecules from the surface. In order to decrease the process time for practical applications, a water pulse time as low as $2 \mathrm{~s}$ is desirable.

\section{Ozone process}

The growth rate of $\mathrm{TiO}_{2}$ films prepared by TTIP and ozone was measured at the same temperature as the TTIP and water process. The TTIP pulse and purge times that were used in this case were $500 \mathrm{~ms}$ and $1 \mathrm{~s}$, respectively. Different $\mathrm{O}_{3}$ pulse times varying from $500 \mathrm{~ms}$ to $5 \mathrm{~s}$ were used, and no marked change in the growth rate was observed between 80 and $120^{\circ} \mathrm{C}$ by varying $\mathrm{O}_{3}$ feeding time, and the growth rate remained constant between 0.1 and $0.12 \AA$ /cycle. The refractive index of the films also was measured in the range of 1.8-1.9. Since these low growth rates and refractive index values would not lead to a practical process, no further studies were carried out with TTIP and ozone.

\section{Plasma oxidation process}

Using oxygen plasma lead to higher growth rates in comparison to water and ozone processes at $80^{\circ} \mathrm{C}$ with the same pulse lengths. The TTIP pulse and purge lengths was $500 \mathrm{~ms}$ and $1 \mathrm{~s}$, respectively, and remained constant for all the deposition conditions. Oxygen plasma pulse length varied between $500 \mathrm{~ms}$ and $5 \mathrm{~s}$ and a $5 \mathrm{~s}$ of purge length was used after the oxygen plasma pulse. Figure 4(a) shows the changes in growth rate and refractive index of titanium dioxide layers with $\mathrm{O}_{2}$ plasma pulse length. The growth rate of titanium dioxide layers deposited by TTIP and oxygen plasma varied between 0.37 and $0.56 \AA /$ cycle. The maximum growth rate of $0.56 \AA /$ cycle occurred with $2 \mathrm{~s}$ of oxygen plasma pulse and plasma power of $250 \mathrm{~W}$. As is shown in the graph, the growth rate initially increases with increasing $\mathrm{O}_{2}$ pulse length and drops after reaching a maximum. Using longer $\mathrm{O}_{2}$ pulse times resulted in lower growth rates but as the $\mathrm{O}_{2}$ pulse length increases, refractive index of the films increases which shows the films become denser. ${ }^{47}$ The refractive indices of the films deposited by TTIP and oxygen plasma 

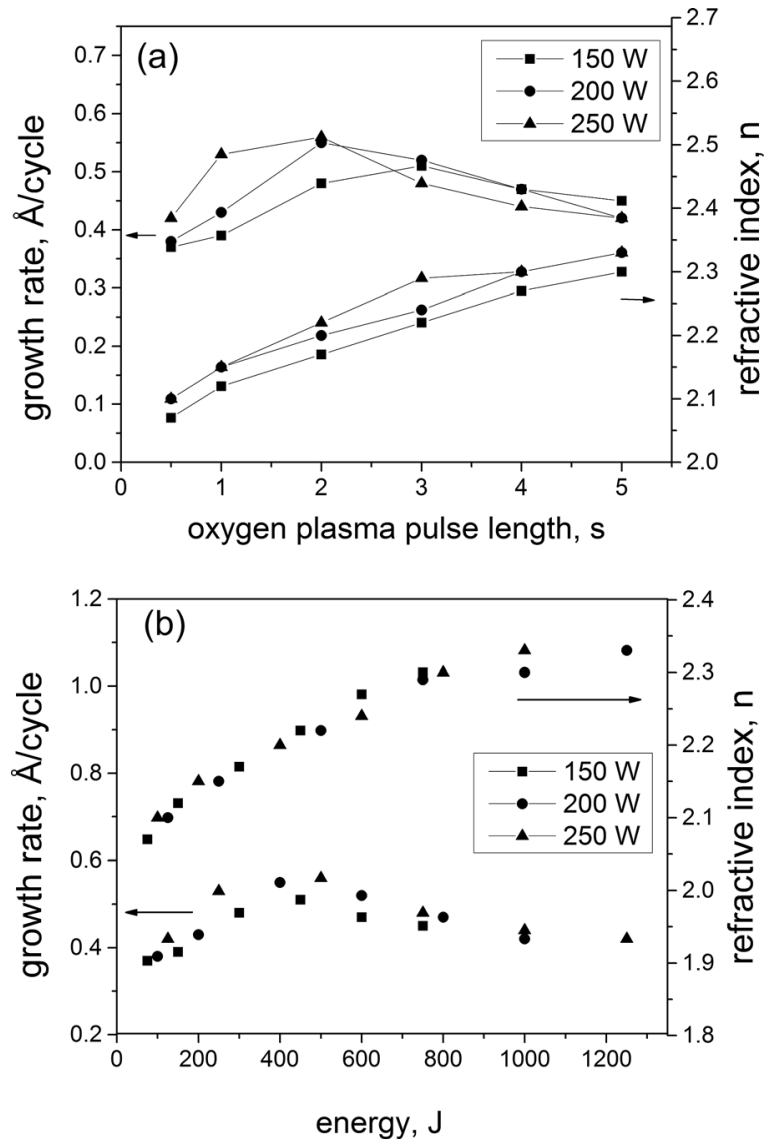

FIG. 4. (a) Growth rate and refractive index of $\mathrm{TiO}_{2}$ Films as a function of oxygen plasma pulse length and (b) energy input to the plasma.

measured between 2.07 and 2.33 and are higher than the films that were deposited by TTIP and water, which indicates that plasma is able to make denser films. Changing plasma power also affects both growth rate and refractive index of the resultant films. Generally, the measured growth rate was higher for the higher plasma power. The refractive index increased when the plasma power was increased from 150 to $250 \mathrm{~W}$. The maximum growth rate occurred at longer plasma pulse times for lower plasma power. To illustrate this, the growth rate and refractive index data are plotted as a function of the energy input to the plasma, as shown in Fig. 4(b). This shows that the plasma energy is the driver of the reactions and indicates that much shorter plasma pulses could be used if the power is increased. This is due to the effect of increasing reactivity of oxygen plasma with increasing plasma power. ${ }^{48}$ With increasing plasma power, removal of TTIP ligands from the surface also takes place more efficiently.

The growth rates measured using TTIP and oxygen plasma in the present study are in good agreement with previous studies with the same temperature range. ${ }^{49,50} \mathrm{In}$ comparison to the water process, plasma deposition helps to decrease overall process time by decreasing the purge time after oxidant precursor exposure. There also exists the possibility of generating water during plasma-assisted ALD, due to the reaction of the oxygen radicals with hydrocarbons from the TTIP, but the amount of water that is produced in this case is does not significantly affect the process time.

\section{B. Properties of $\mathrm{TiO}_{2}$ layers deposited by temporal ALD}

\section{X-ray photoelectron spectroscopy}

The results of elemental analysis, which was performed on samples deposited with different deposition conditions, are shown in Table I. Three samples from the films deposited by TTIP and water at 80,100 , and $120^{\circ} \mathrm{C}$ were selected for XPS measurements. For TTIP and oxygen plasma, the samples deposited with the plasma power of $200 \mathrm{~W}$ and different pulse lengths were selected to study the effects of oxygen plasma exposure on the film chemical composition. Moreover, two samples that were deposited by 150 and $250 \mathrm{~W}$ were selected to survey the effects of plasma power. The measurements were done before and after $20 \mathrm{~s}$ of $\mathrm{Ar}^{+}$ ion bombardment. The high level of carbon content in asdeposited samples is related to surface $\mathrm{C}-\mathrm{C}$ and $\mathrm{C}-\mathrm{H}$ contaminations as the $\mathrm{C} 1 \mathrm{~s}$ peak in the binding energy of $284.7 \mathrm{eV}$ for all the films confirms this issue. ${ }^{51}$

It was found that the content of residual carbon in the films grown by the thermal ALD process with $\mathrm{H}_{2} \mathrm{O}$ as an oxidant remained constant within the error of XPS measurements. The mechanism of reaction between TTIP and water is much simpler than in the case of TTIP and oxygen plasma. In the water process, at temperatures between 80 and $120^{\circ} \mathrm{C}$, precursor decomposition does not take place and the only reactant surface group after TTIP exposure is the surface $-\mathrm{OH}$ group. ${ }^{38} \mathrm{~A}$ considerable change was observed in the carbon content of the films deposited by TTIP and oxygen plasma for different oxygen plasma pulse lengths. The carbon content decreased with increasing oxygen plasma pulse length from $5.1 \%$ for a $0.5 \mathrm{~s}$ oxygen plasma pulse length to $3 \%$ for a $2 \mathrm{~s}$ oxygen plasma pulse length and negligible amount of carbon was detected for $5 \mathrm{~s}$ of oxygen plasma pulse length. Changing plasma power also affected the carbon content of the films. As it can be seen in Table I, the carbon content gradually decreased when increasing the plasma power from 150 to $250 \mathrm{~W}$. Comparing them in terms of plasma energy also suggests that the carbon content is a function of plasma energy input and decreases with

TABLE I. Carbon content of $\mathrm{TiO}_{2}$ films deposited by temporal ALD (after $\mathrm{Ar}^{+}$sputtering).

\begin{tabular}{lcccc}
\hline \hline Reactant & $\begin{array}{c}\text { Plasma } \\
\text { power }(\mathrm{W})\end{array}$ & $\begin{array}{c}\text { Temperature } \\
\left({ }^{\circ} \mathrm{C}\right)\end{array}$ & $\begin{array}{c}\text { Pulse } \\
\text { length (s) }\end{array}$ & $\begin{array}{c}\text { Carbon } \\
\text { content } \\
\text { (at. \% } \pm 0.5)\end{array}$ \\
\hline Water & & 80 & 2 & 2.1 \\
& & 100 & 2 & 2.4 \\
Oxygen plasma & 250 & 120 & 2 & 2.0 \\
& 200 & 80 & 0.5 & 4.8 \\
& & 80 & 0.5 & 5.1 \\
& & 80 & 2 & 3.0 \\
& \multirow{2}{*}{150} & 80 & 0.5 & 5.9 \\
\hline \hline
\end{tabular}


increasing the plasma energy. The analysis of the C1s peak of XPS spectra after sputtering for the films deposited by TTIP and both water and oxygen plasma shows that the carbon configurations are different in both films. The deconvolution of the C1s peaks shown in Fig. 5(a) for the films deposited by the thermal $\mathrm{H}_{2} \mathrm{O}$ process consists of two peaks at binding energies of 284.7 and $286 \mathrm{eV}$, which indicate that the carbon bond belongs to a $\mathrm{C}-\mathrm{C}, \mathrm{C}-\mathrm{OH}$ and $\mathrm{C}-\mathrm{O}-\mathrm{C}$ groups in the film. An additional peak at $282 \mathrm{eV}$ is also present in all of them which belongs to Ti-C bond. ${ }^{52,53}$ Since there is no Ti-C bond in the TTIP precursor, the formation of a Ti-C bond can be due to the reducing effect of the sputtering prior to the XPS measurement. The same effect was observed by Sonnenfeld et al. ${ }^{54}$ Lack of Ti-C bonds in the same samples before sputtering also supports the idea of the reducing effect during sputtering. The $\mathrm{C} 1 \mathrm{~s}$ peak of the films deposited by plasma shows a peak at binding energy of $288.8 \mathrm{eV}$ in addition to the peak at $284.7 \mathrm{eV}$ [Fig. 5(b)]. The binding energy of $288.8 \mathrm{eV}$ corresponds to $\mathrm{O}=\mathrm{C}-\mathrm{O}$ functional groups in the film. ${ }^{55,56}$ It has been reported that both metal carbonates and hydroxyl are reactive sites for TTIP chemisorption in plasma-assisted ALD of $\mathrm{TiO}_{2} .{ }^{57}$ The reaction between $\mathrm{O}$ radicals and organic ligands produces $\mathrm{H}_{2} \mathrm{O}$, $\mathrm{CO}$, and $\mathrm{CO}_{2}$. Moreover, surface carbonates and bicarbonates are known to be formed due to simultaneous reaction of $\mathrm{H}_{2} \mathrm{O}$ and $\mathrm{CO}_{2}$ with a metal oxide surface. ${ }^{58}$ Incorporation of $\left(\mathrm{CO}_{3}{ }^{2-}\right)$ in addition to -OH surface group in the plasma process possibly leaves some carbon within the film structure. Changes in relative fraction of the two types of surface reactive site with changing plasma pulse length are the most probable reason for the small amount of carbon in higher plasma pulses. The $\left(\mathrm{CO}_{3}{ }^{2-}\right)$ groups are superseded by $-\mathrm{OH}$ surface groups by prolonging the oxygen plasma pulse length.

Deconvolution of Ti2p spectra into Gaussian peaks for the samples before $\mathrm{Ar}^{+}$ion etching indicates two $\mathrm{Ti} 2 \mathrm{p}_{2 / 3}$

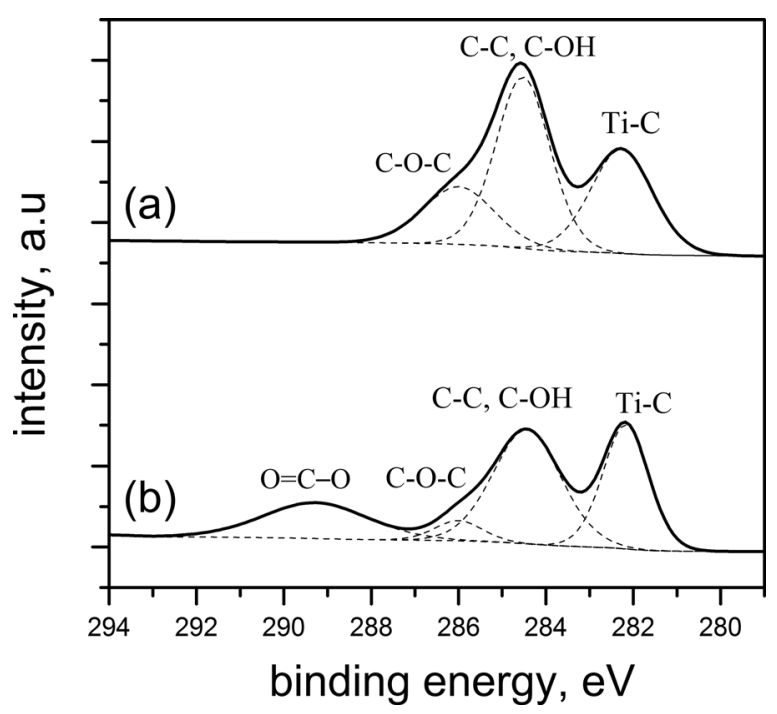

FIG. 5. C1s peaks of XPS spectra for (a) TTIP and water (water pulse length: $2 \mathrm{~s}, 100^{\circ} \mathrm{C}$ ) and (b) TTIP and oxygen plasma (oxygen plasma pulse length: $2 \mathrm{~s}$ ). peaks at binding energies of 458.5 and $457.1 \mathrm{eV}$ which correspond to $\mathrm{Ti}(\mathrm{IV})$ and $\mathrm{Ti}(\mathrm{III})$ oxidation states, respectively. ${ }^{59,60}$ The intensity ratio of $I\left(\mathrm{Ti}^{3+}\right) / I\left(\mathrm{Ti}^{4+}\right)$ varies between 0.01 and 0.03 , which shows the negligible amount of Ti (III) oxidation state. The state of oxidation changed partially from $\mathrm{Ti}$ (IV) to $\mathrm{Ti}$ (III) after $\mathrm{Ar}^{+}$ion etching as previously reported in several studies. ${ }^{61-64}$

\section{Water vapor transmission rate}

WVTR measurements were performed on the series of $\mathrm{TiO}_{2}$ films with the thickness of 10,20 , and $45 \mathrm{~nm}$ deposited on PEN. The WVTR value of the pristine PEN was measured to be $1 \mathrm{~g}$ day ${ }^{-1} \mathrm{~m}^{-2}$. Forty five nanometer thick $\mathrm{TiO}_{2}$ (TTIP and water) decreased the water permeation rate to the level of $3 \times 10^{-2} \mathrm{~g} \mathrm{day}^{-1} \mathrm{~m}^{-2}$. The precursor pulse and purge sequence for these films was: $500 \mathrm{~ms}$ TTIP pulse, $1 \mathrm{~s}$ TTIP purge, $2 \mathrm{~s}$ water pulse and $25 \mathrm{~s}$ water purge. A water pulse time of $2 \mathrm{~s}$ was selected to avoid excess water accumulation on the surface during the coating process and decrease the overall process time. Figure 6 shows the changes in WVTR values of $\mathrm{TiO}_{2}$ coated PEN using TTIP and water with temperature. As the temperature increases, the WVTR value decreases.

The $\mathrm{TiO}_{2}$ films deposited by TTIP and oxygen plasma showed a lower level of moisture permeation. Figure 7 shows the variation of WVTR value for the samples by different thickness made by different plasma $(200 \mathrm{~W})$ pulse length. The TTIP pulse and purge times were the same times that were used in water process. Different oxygen plasma pulse lengths of $500 \mathrm{~ms}, 2 \mathrm{~s}$ and $5 \mathrm{~s}$ were used and a $5 \mathrm{~s}$ purge after oxygen plasma pulse. The WVTR value for $45 \mathrm{~nm}$ of the film with prepared by $500 \mathrm{~ms}$ oxygen plasma pulse length turned out to be $1 \times 10^{-3} \mathrm{~g}_{\text {day }}{ }^{-1} \mathrm{~m}^{-2}$, which is still lower than the best value for the film deposited by the water process. For both 2 and $5 \mathrm{~s}$ of pulse length and thicknesses of more than $20 \mathrm{~nm}$, the WVTR values were measured lower than the measurement limit of the equipment (lower than $5 \times 10^{-4} \mathrm{~g} \mathrm{day}^{-1} \mathrm{~m}^{-2}$ ). These low values could be attributed to the dense and conformal nature of the films prepared using

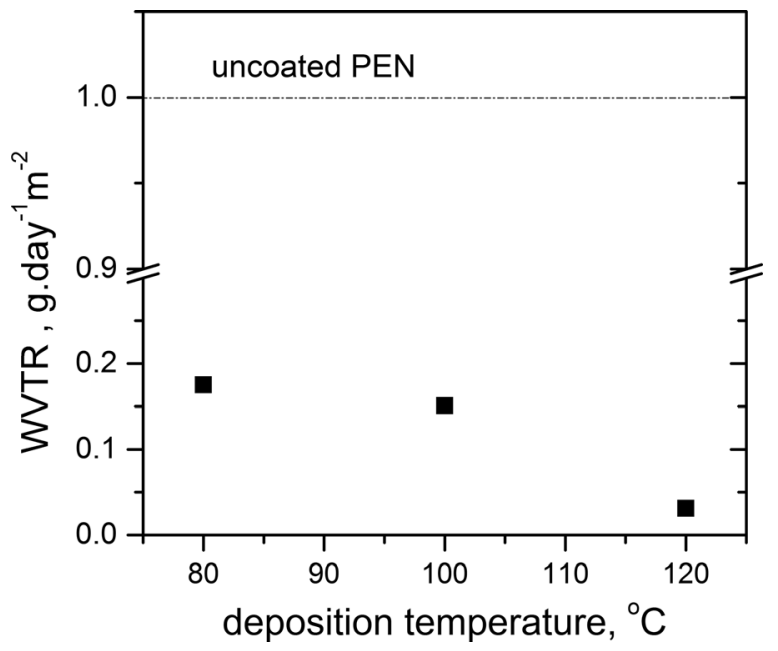

FIG. 6. WVTR of the films deposited by TTIP and water. 


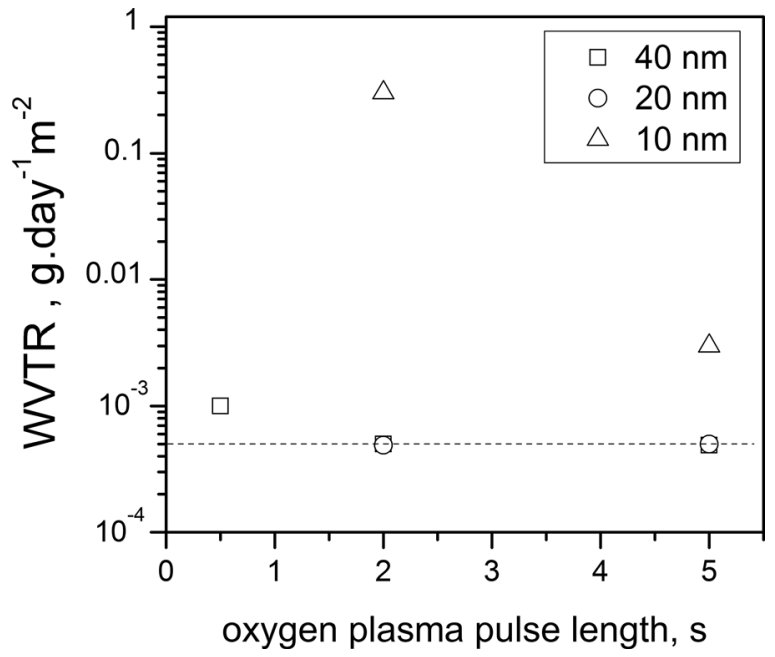

FIG. 7. WVTR of the films deposited by TTIP and oxygen plasma.

plasma-assisted ALD. By decreasing the film thickness down to $10 \mathrm{~nm}$, the WVTR value for 2 and $5 \mathrm{~s}$ of oxygen plasma length increased to $3 \times 10^{-1} \mathrm{~g}$ day $^{-1} \mathrm{~m}^{-2}$ and $3 \times 10^{-3} \mathrm{~g} \mathrm{day}^{-1} \mathrm{~m}^{-2}$, respectively.

Kim et al. ${ }^{27}$ measured the WVTR value for $80 \mathrm{~nm}$ titanium dioxide layer deposited by TDMAT and oxygen plasma on PES at the substrate temperature of $90^{\circ} \mathrm{C}$. They reported $2.3 \times 10^{-2} \mathrm{~g} \mathrm{day}^{-1} \mathrm{~m}^{-2}$ in measurement condition of $37.8^{\circ} \mathrm{C}$ and $100 \% \mathrm{RH}$. WVTR values in the level of $10^{-1}$ for 40-60 nm thick $\mathrm{TiO}_{2}$ ALD layer on PES substrate were measured by Han et al. ${ }^{65}$ They also used TDMAT and oxygen plasma at $80^{\circ} \mathrm{C}$ to deposit $\mathrm{TiO}_{2}$ and the WVTR measurement condition was $38^{\circ} \mathrm{C}$ and $100 \%$ RH. Dickey and Barrow ${ }^{66}$ reported the WVTR values down to the equipment measurement limit $\left(5 \times 10^{-4}\right)$ for $8 \mathrm{~nm}$ of $\mathrm{TiO}_{2}$ layer on PET deposited using a plasma assisted roll-to-roll ALD system. In this case, measurements were made at $38^{\circ} \mathrm{C}$ and $90 \% \mathrm{RH}$. In this study, since the limit for the measurement instrument was $5 \times 10^{-4} \mathrm{~g}$ day $^{-1} \mathrm{~m}^{-2}$, the values lower than this value could not be measured and the exact value of WVTR for 20 and $40 \mathrm{~nm}$ of $\mathrm{TiO}_{2}$ deposited by TTIP and oxygen plasma remained unknown. A calcium test or similar is needed to measure lower values of WVTR.

The water vapor transmission rate through the film is determined by four stages of adsorption, solubilization, diffusion, and desorption. ${ }^{67}$ The density and size of defects inside the film are determinant factors for the diffusion thorough the film. ${ }^{68}$ The denser ALD films, which contain narrower and more widely separated pathways for water permeation, can hinder this diffusion of moisture through the film. ${ }^{69}$ The level of nanoporosity inside thin films also is known as a factor, which is correlated to the water permeation of ALD layers. ${ }^{70}$ Depending on the process conditions, e.g., water or plasma exposure time, plasma power and deposition temperature, which directly affect the film microstructure and physical properties, the density and size of pores inside the film structure can be different. As it can be seen from Fig. 3 for the water process, the refractive index of the films increases with increase of temperature which suggests that the films are becoming denser. Increasing the oxygen plasma pulse length also led to the production of denser films and in consequence lower WVTR values. It can be therefore concluded that the water permeation decreased with increasing film density.

\section{Spatial ALD of TTIP and water}

The results of growth rate, refractive index, and elemental analysis of titanium dioxide films deposited by Spatial ALD system using TTIP and water as precursors are presented in this section. Figure 8(a) shows the growth rate of spatially deposited titanium dioxide as a function of residence time and rotations per minute (rpm) at three deposition temperatures. Changes in deposition temperature showed insignificant effects on the growth rate. The growth rate increased with increasing residence time and saturated at about $0.35 \AA$ / cycle for all the three deposition temperatures. This value is slightly higher than the saturated growth in temporal ALD of TTIP and water [Fig. 3(a)]. Increasing the residence time above $459 \mathrm{~ms}$ ( $5 \mathrm{rpm}$ ) showed no considerable change in the growth rate for all the three temperatures. One feature of the SALD system is that the precursor exposure time and the purging time cannot be independently varied since their ratio is fixed by the mechanical dimensions of reaction chamber. However, as in conventional ALD, the precursor dose is a combination of the precursor exposure time and the precursor vapor pressure. The purging time will, of course, depend
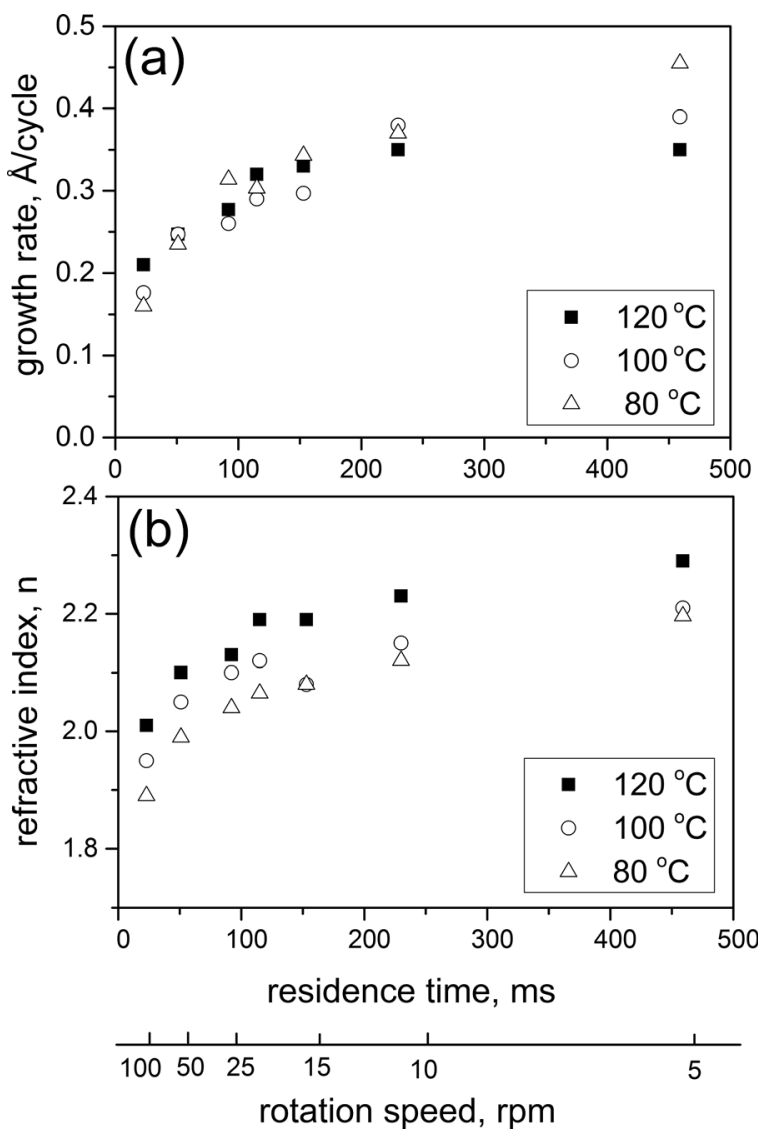

FIG. 8. (a) Growth rate and (b) refractive index of $\mathrm{TiO}_{2}$ films deposited by spatial ALD. 
on the rotation speed. Therefore, a balance between the precursor dose and the purging time can be achieved, which will minimize the amount of excess water and other byproducts that needs to be removed from the film surface. This enables a fast ALD cycle to be achieved in SALD. A decrease in deposition temperature to $80^{\circ} \mathrm{C}$ showed no anomalous growth at low residence times (high speed deposition) as was reported by Maydannik et al. ${ }^{46}$ for $\mathrm{Al}_{2} \mathrm{O}_{3}$ deposited using trimethylaluminum (TMA) and water in the same type of spatial ALD reactor. They explained this anomalous growth by formation of water multilayers at substrate temperature lower than $100^{\circ} \mathrm{C}$, leading to a CVD reaction between the excess water and the incoming TMA precursor. The absence of such CVD growth behavior over a wide range of residence time for TTIP and water suggests that this explanation does not hold. Figure 8(b) shows the change in refractive index of spatially deposited titanium dioxide layers using TTIP and water with residence time at three deposition temperatures. All the curves reach a saturation at the residence time of $230 \mathrm{~ms}$. Similar to temporal ALD, it can be seen that the refractive index is higher for the higher temperatures at a given residence time. Comparing to the films produced by temporal ALD, the refractive index of the films produced by spatial ALD is slightly higher at the same temperature and in the saturated mode.

XPS analysis was carried out in order to compare the spatially deposited titanium dioxide films with those deposited by temporal ALD. Table II shows the carbon content of the samples with various residence times and deposited in different temperatures. In each temperature, the carbon content of the sample deposited by $153 \mathrm{~ms}$ of residence time is similar to the one deposited by temporal ALD and in saturated mode. Increasing the residence time to $459 \mathrm{~ms}$ has led to small changes in carbon content and no change in the case of the samples deposited at $100^{\circ} \mathrm{C}$. The origin of the relatively higher carbon content with higher speed deposition $(100 \mathrm{rpm})$ is the result of incomplete reaction between incoming $\mathrm{H}_{2} \mathrm{O}$ molecules and the TTIP surface ligands, which are consequently trapped in the film and increase the residual carbon inside the films. The lower purge time might also contribute, as some of methyl groups remaining from the previous reaction might be carried into the next half reaction zone due to the incomplete purge. With increasing residence time, there will be more time for surface ligands and incoming precursors to react and also be removed in the purge zones. Therefore, purer films with lower carbon contamination will be produced with increasing residence time. Increasing the residence time after reaching saturation at $153 \mathrm{~ms}$ showed little change in carbon content, film growth rate, or refractive index. The $\mathrm{C} 1 \mathrm{~s}$ peaks of the SALD $\mathrm{TiO}_{2}$

TABLE II. Carbon content of SALD samples.

\begin{tabular}{lccc}
\hline \hline & \multicolumn{3}{c}{$\mathrm{C} \% \pm 0.5$} \\
\cline { 2 - 4 } Residence time $(\mathrm{ms})$ & $80^{\circ} \mathrm{C}$ & $100{ }^{\circ} \mathrm{C}$ & $120^{\circ} \mathrm{C}$ \\
\hline $23(100 \mathrm{rpm})$ & 4.5 & 4.1 & 2.7 \\
$153(15 \mathrm{rpm})$ & 2.0 & 2.3 & 2.3 \\
$459(5 \mathrm{rpm})$ & 2.7 & 2.3 & 1.8 \\
\hline \hline
\end{tabular}

samples were the same as the peaks that were observed for the water process in temporal ALD [Fig. 5(a)]. Deconvoluting the C1s peaks of the XPS spectra showed that $\mathrm{C}-\mathrm{C}, \mathrm{C}-\mathrm{OH}$, and $\mathrm{C}-\mathrm{O}-\mathrm{C}$ are the functional groups which are present in the $\mathrm{TiO}_{2}$ layers deposited by SALD using TTIP and water.

By increasing the temperature from 80 to $120^{\circ} \mathrm{C}$, the carbon content in the films slightly decreased. At high deposition rates $(100 \mathrm{rpm})$, it is still possible to have the carbon content as low as $2.7 \%$ at $120^{\circ} \mathrm{C}$. Comparing the growth rate, refractive index, and chemical analysis shows that the same results of the temporal ALD can be obtained by spatial ALD with considerably lower deposition time, which shows the capability of spatial ALD to produce titanium dioxide films with the same film quality of temporal ALD. However, the increased growth rate in the SALD process compared to the temporal process might be explained by a slight CVD component, which may occur in the SALD process since dosing and purging time cannot be controlled independently.

\section{CONCLUSIONS}

$\mathrm{TiO}_{2}$ thin films have been deposited by thermal and plasma-assisted temporal ALD and also SALD at low temperatures $\left(\leq 120^{\circ} \mathrm{C}\right)$ using TTIP as the Ti precursor. In the thermal process with water as the oxidant, the effect of temperature variation between 80 and $120^{\circ} \mathrm{C}$ on deposition rate was minimal; nevertheless, the density of the films increased with an increase of temperature. The process with ozone as the oxidant had low growth rate at these temperatures and is not practically useful. In plasma-assisted ALD, the length of the oxygen plasma pulse played an important role in both purity and density of the layers. The WVTR measurements on $\mathrm{TiO}_{2}$ films deposited on PEN indicated that for temporal ALD the plasma-assisted process produces better moisture barrier layers and WVTR values lower than $5 \times 10^{-4} \mathrm{~g}$ day ${ }^{-1} \mathrm{~m}^{-2}$ were obtained for $20 \mathrm{~nm}$ of $\mathrm{TiO}_{2}$ films deposited on PEN using more than $2 \mathrm{~s}$ of oxygen plasma pulse length. The SALD process using TTIP and water showed similar growth rate and quality to the layers produced by temporal ALD. The production rate of SALD $\mathrm{TiO}_{2}$ films is greater than temporal ALD for similar film characteristics. For comparison, further studies using oxygen plasma as an oxidant source in SALD will be carried out in due course.

\section{ACKNOWLEDGMENTS}

Thanks are due to Alexander Plyushch for carrying out the SALD depositions. This research was funded by the Finnish Funding Agency for Technology and Innovation (TEKES) under project 652/31/2013.

${ }^{1}$ S. M. George, Chem. Rev. 110, 111 (2010).

${ }^{2}$ O. Sneh, R. B. Clark-Phelps, A. R. Londergan, J. Winkler, and T. E. Seidel, Thin Solid Films 402, 248 (2002).

${ }^{3}$ J. Haümaülaüinen, T. Sajavaara, E. Puukilainen, M. Ritala, and M. Leskelä, Chem. Mater. 24, 55 (2012).

${ }^{4}$ H. Kim, J. Vac. Sci. Technol. B 21, 2231 (2003).

${ }^{5}$ S. D. Elliott, Langmuir 26, 9179 (2010).

${ }^{6}$ H. Kim, H. B. R. Lee, and W. J. Maeng, Thin Solid Films 517, 2563 (2009). 
${ }^{7}$ P. S. Maydannik et al., J. Vac. Sci. Technol. A 32, 051603 (2014).

${ }^{8}$ P. Poodt, D. C. Cameron, E. Dickey, S. M. George, V. Kuznetsov, G. N. Parsons, F. Roozeboom, G. Sundaram, and A. Vermeer, J. Vac. Sci. Technol. A 30, 010802 (2012).

${ }^{9}$ W. M. M. Kessels and M. Putkonen, MRS Bull. 36, 907 (2011).

${ }^{10}$ K. Lahtinen, P. Maydannik, P. Johansson, T. O. Kääriäinen, D. C. Cameron, and J. Kuusipalo, Surf. Coat. Technol. 205, 3916 (2011).

${ }^{11}$ P. Poodt, A. Lankhorst, F. Roozeboom, K. Spee, D. Maas, and A. Vermeer, Adv. Mater. 22, 3564 (2010).

${ }^{12}$ C.-Y. Chang, F.-Y. Tasi, S.-J. Jhuo, and M.-J. Chen, Org. Electron. 9, 667 (2008).

${ }^{13}$ J. Park, Y. Y. Noh, J. W. Huh, J. Lee, and H. Chu, Org. Electron. 13, 1956 (2012).

${ }^{14}$ Y. C. Han, E. Kim, W. Kim, H.-G. Im, B. S. Bae, and K. C. Choi, Org. Electron. 14, 1435 (2013).

${ }^{15}$ M. D. Groner, F. H. Fabreguette, J. W. Elam, and S. M. George, Chem. Mater. 16, 639 (2004).

${ }^{16}$ G. Triani, J. A. Campbell, P. J. Evans, J. Davis, B. A. Latella, and R. P. Burford, Thin Solid Films 518, 3182 (2010).

${ }^{17}$ S. E. Potts, H. B. Profijt, R. Roelofs, and W. M. M. Kessels, Chem. Vap. Deposition 19, 125 (2013).

${ }^{18}$ T. Nam, J. M. Kim, M. K. Kim, W. H. Kim, and H. Kim, J. Korean Phys. Soc. 59, 452 (2011).

${ }^{19}$ J. Wöhle, H. Ahn, and K.-T. Rie, Surf. Coat. Technol. 116, 1166 (1999).

${ }^{20}$ E. Langereis, M. Creatore, S. B. S. Heil, M. C. M. van de Sanden, and W. M. M. Kessels, Appl. Phys. Lett. 89, 081915 (2006).

${ }^{21}$ C. L. Beyler and M. M. Hirschler, SFPE Handbook of Fire Protection Engineering (National Fire Protection Association, Quincy, MA, 2008).

${ }^{22}$ S. H. Jen, S. M. George, R. S. McLean, and P. F. Carcia, Appl. Mater. Interfaces 5, 1165 (2013).

${ }^{23}$ W. Fang and C. Y. Lo, Sens. Actuators Phys. 84, 310 (2000).

${ }^{24}$ G. Krautheim, T. Hecht, S. Jakschik, U. Schröder, and W. Zahn, Appl. Sur. Sci. 252, 200 (2005).

${ }^{25}$ M. D. Groner, S. M. George, R. S. McLean, and P. F. Carcia, Appl. Phys. Lett. 88, 051907 (2006).

${ }^{26}$ T. S. Kwon, D. Y. Moon, Y. K. Moon, W. S. Kim, and J. W. Park, J. Nanosci. Nanotechnol. 12, 3696 (2012).

${ }^{27}$ W. S. Kim, M. G. Ko, T. S. Kim, S. K. Park, Y. K. Moon, S. H. Lee, J. G. Park, and J. W. Park, J. Nanosci. Nanotechnol. 8, 4726 (2008).

${ }^{28}$ J. Aarik, A. Aidla, H. Mändar, and T. Uustare, Appl. Surf. Sci. 172, 148 (2001).

${ }^{29}$ J. Aarik, A. Aidla, T. Uustare, K. Kukli, V. Sammelselg, M. Ritala, and M. Leskelä, Appl. Surf. Sci. 193, 277 (2002).

${ }^{30}$ Q. Tao, K. Overhage, G. Jursich, and C. Takoudis, Thin Solid Films 520, 6752 (2012).

${ }^{31}$ J. Aarik, A. Aidla, T. Uustare, M. Ritala, and M. Leskelä, Appl. Surf. Sci. 161, 385 (2000).

${ }^{32}$ J. Aarik, J. Karlis, H. Mandar, T. Uustare, and V. Sammelselg, Appl. Surf. Sci. 181, 339 (2001).

${ }^{33}$ A. P. Alekhin, S. A. Gudkova, A. M. Markeev, A. S. Mitiaev, A. A. Sigarev, and V. F. Toknova, Appl. Surf. Sci. 257, 186 (2010).

${ }^{34}$ T. O. Kääriäinen and D. C. Cameron, Plasma Processes Polym. 6, S237 (2009).

${ }^{35}$ M. Kariniemi, J. Niinistö, M. Vehkamäki, M. Kemell, M. Ritala, M. Leskelä, and M. Putkonen, J. Vac. Sci. Technol. A 30, 01 A115 (2012).

${ }^{36}$ Q. Xie, Y.-L. Jiang, C. Detavernier, D. Deduytsche, R. L. Van. Meirhaeghe, G.-P. Ru, B.-Z. Li, and X.-P. Qu, J. Appl. Phys. 102, 083521 (2007).

${ }^{37}$ A. Rahtu and M. Ritala, Chem. Vap. Deposition 8, 21 (2002).
${ }^{38}$ M. Ritala and M. Leskelii, Chem. Mater. 5, 1174 (1993).

${ }^{39}$ H. Döring, K. Hashimoto, and A. Fujishima, Ber. Bunsenges. Phys. Chem. 96, 620 (1992).

${ }^{40}$ A. Sinha, D. W. Hess, and C. L. Henderson, J. Vac. Sci. Technol. B 24, 2523 (2006).

${ }^{41}$ X. Meng, M. N. Banis, D. Geng, X. Li, Y. Zhang, R. Li, H. Abou-Rachid, and X. Sun, Appl. Surf. Sci. 266, 132 (2013).

${ }^{42}$ S. E. Potts, W. Keuning, E. Langereis, G. Dingemans, M. C. M. van de Sanden, and W. M. M. Kessels, J. Electrochem. Soc. 157, P66 (2010).

${ }^{43}$ A. C. Dillon, A. W. Ott, J. D. Way, and S. M. George, Surf. Sci. 322, 230 (1995).

${ }^{44}$ A. W. Ott, J. W. Klaus, J. M. Johnson, and S. M. George, Thin Solid Films 292, 135 (1997).

${ }^{45}$ R. Matero, A. Rahtu, M. Ritala, M. Leskelä, and T. Sajavaara, Thin Solid Films 368, 1 (2000).

${ }^{46}$ P. S. Maydannik, T. O. Kääriäinen, and D. C. Cameron, J. Vac. Sci. Technol. A 30, 01A122 (2012).

${ }^{47}$ C. R. Ottermann, K. Bange, W. Wagner, M. Laube, and F. Rauch, Surf. Interface Anal. 19, 435 (1992).

${ }^{48}$ J. G. Lee, H. G. Kim, and S. S. Kim, Thin Solid Films 534, 515 (2013).

${ }^{49}$ Q. Xie et al., J. Electrochem. Soc. 155, H661 (2008).

${ }^{50}$ J. Lee, S. J. Lee, W. B. Han, H. Jeon, J. Park, W. Jang, C. S. Yoon, and H. Jeon, Phys. Status Solidi A 210, 276 (2013).

${ }^{51}$ T. O. Kääriäinen, S. Lehti, M.-L. Kääriäinen, and D. C. Cameron, Surf. Coat. Technol. 205, S475 (2011).

${ }^{52}$ S. Zhang, Y. Q. Fu, X. L. Bui, and H. J. Du, Int. J. Nanosci. 3, 797 (2004).

${ }^{53}$ S. J. Wang, H. Y. Tsai, and S. C. Sun, J. Electrochem. Soc. 148, C563 (2001).

${ }^{54}$ A. Sonnenfeld, R. Hauert, and P. R. Von Rohr, Plasma Chem. Plasma Process. 26, 319 (2006).

${ }^{55}$ N. Ohtsu, N. Masahashi,Y. Mizukoshi, and K. Wagatsuma, Langmuir 25, 11586 (2009).

${ }^{56}$ S.-H. Lee, E. Yamasue, K. N. Ishihara, and H. Okumura, Appl. Catal. B 93, 217 (2010).

${ }^{57}$ V. R. Rai and S. Agarwal, J. Phys. Chem. C 113, 12962 (2009).

${ }^{58}$ M. A. Henderson, Surf. Sci. 400, 203 (1998).

${ }^{59}$ A. R. González-Elipe, G. Munuera, J. P. Espinos, and J. M. Sanz, Surf. Sci. 220, 368 (1989).

${ }^{60}$ M. C. Biesinger, L. W. M. Lau, A. R. Gerson, and R. S. C. Smart, Appl. Surf. Sci. 257, 887 (2010).

${ }^{61}$ S. Hashimoto, C. Tanaka, A. Murata, and T. Sakurada, J. Surf. Anal. 13, 14 (2006).

${ }^{62}$ S. Hashimoto, A. Murata, T. Sakurada, and A. Tanaka, J. Surf. Anal. 9, 459 (2002).

${ }^{63}$ S. Hashimoto, A. Tanaka, A. Murata, and T. Sakurada, Surf. Sci. 556, 22 (2004).

${ }^{64}$ E. McCafferty and J. P. Wightman, Appl. Surf. Sci. 143, 92 (1999).

${ }^{65}$ D. S. Han, D. K. Choi, and J. W. Park, Thin Solid Films 552, 155 (2014).

${ }^{66}$ E. Dickey and W. A. Barrow, J. Vac. Sci. Technol. A 30, 021502 (2012).

${ }^{67}$ A. S. da Silva Sobrinho, G. Czeremuszkin, M. Latrèche, and M. R. Wertheimer, J. Vac. Sci. Technol. A 18, 149 (2000).

${ }^{68}$ G. L. Graff, R. E. Williford, and P. E. Burrows, J. Appl. Phys. 96, 1840 (2004).

${ }^{69}$ A. G. Erlat, B. M. Henry, C. R. M. Grovenor, A. G. D. Briggs, R. J. Chater, and Y. Tsukahara, J. Phys. Chem. B 108, 883 (2004).

${ }^{70}$ A. Perrotta, E. R. J. Beekum, G. Aresta, A. Jagia, W. Keuning, M. C. M Sanden, W. M. M. Kessels, and M. Creatore, Microporous Mesoporous Mater. 188, 163 (2014). 